\title{
Impacts Of Accountability Indicators And Socioeconomic Factors On Test Scores And Policy Implications
}

Michael Craig Budden, (Email: mbudden@ selu.edu), Southeastern Louisiana University Yu Hsing, (Email: yhsing@ @elu.edu), Southeastern Louisiana University

\begin{abstract}
Based on a sample of 63 school districts in the state of Louisiana during academic year 2003-2004, we find that a higher (IOWA) test score is associated with higher attendance rates, smaller class sizes, more qualified teachers, more discipline, less spending per student, lower poverty rates, and lower per capita personal income. Therefore, we need to continue to pursue qualified teachers, smaller class sizes, and more discipline.
\end{abstract}

\section{INTRODUCTION}

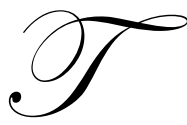

o improve the public education system and to create a productive workforce, the Louisiana legislature created the School and District Accountability Commission in 1997 to design and monitor the state's Public Education Accountability System. Among other things, the Commission published the district performance score (DPS) to analyze the strengths and weaknesses of public schools and districts. In the last several years, statistics indicate some progress and some concerns. The overall DPS increased from 69.4 in 1999 to 82.6 in 2003. In $2003-2004,93.5 \%$ of classes were taught by teachers who were fully certified, and the remaining had nonstandard certification. Teachers possessing masters or doctoral degrees account for $36.6 \%$ of all teachers. The dropout rate decreased to $7.0 \%$. The 2004 ACT score for Louisiana remained at 19.8, which was below the national average of 20.9. Twenty-one percent of schools were in decline.

Because of the importance of academic performance in determining whether a student may be eligible for the state TOPS (Tuition Opportunity Program for Students) scholarship, it is time to examine possible relationships between test scores and these indicators in order to provide public policy makers insight in reviewing the strengths and weaknesses of public education. The paper has several unique aspects. First, the sample comes from all the parishes so that its outcomes can be applied to local school districts. Second, the paper considers several policy and socioeconomic variables such as percent of qualified teachers, percent of students receiving suspension, spending per student, and poverty rates. The sign and significance of each of these variables may have important policy implications. We may find some answers as to how to allocate limited resources to competing needs to meet one of our goals of achieving a higher test score.

\section{LITERATURE SURVEY}

There are several recent studies on possible factors impacting test scores and other related subjects. Dynarski (1985) was among the first to investigate the determinants of SAT scores across states. According to his findings, a higher participation rate increased test scores. Other factors include higher teacher compensation, higher participation by private school students, more participation by population from central cities, a smaller proportion of black population, and a higher proportion of students living with both parents.

Sander and Krautmann (1991) examined three determinants for educational outcomes including ACT scores for the state of Illinois. They found, among other things, that higher ACT scores led to more job opportunities at the 
county level and that spending per student did not affect ACT scores. Instead, ACT scores were influenced by family background such as parent income and education, and the parent's marital status. Sander (1993) later did a second study to measure educational outcomes for the state of Illinois. He showed that higher teachers' salary led to higher ACT scores and that an increase in the student-teacher ratio caused the percent of college-bound students to decline. There is a need to examine the impact of TOPS on ACT scores since its inception in 1998.

Graham and Husted (1993) used the 1991 SAT scores across states as the dependent variable and found that state participation rates, parents' educational level, sex, race, and income are important determinants of SAT scores. Husted and Kenny (2000) examined the impacts of state regulation and subsidies on SAT scores. Their findings based on state SAT scores during 1987 - 1992 supported the hypotheses that some state regulations increase workloads and make school operations less efficient and that state programs to mitigate inequality in the education budget make voters less concerned about school quality.

Card and Payne (1998) studied the impact of state spending equalization on SAT scores and found that it reduced the disparity of test outcomes across districts and different background groups. Based on the experiment of the Tennessee STAR program, Krueger and Whitmore (2001) analyzed whether past experience of small classes would affect test outcomes and whether they would take an ACT or a SAT exam. They found that those children who had small class experiences scored better and had a higher probability to take an ACT or a SAT exam. Furthermore, the small class experience narrowed the test difference of the white-black group by 54 percent.

\section{THE MODEL}

Extending previous studies and based on educational and economic theories, test scores for a parish school district can be expressed as

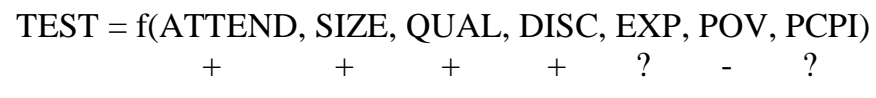

where



We expect that higher test scores are associated with a higher attendance rate, smaller class sizes, more percent of qualified teachers, more discipline, and lower poverty rates. A smaller class size is conductive to learning and would help improve test scores. The certification of teachers is a core program of the state's accountability system so that teachers are qualified to teach in their disciplines or catch up with new knowledge or skills. More discipline as measured by the percent of students receiving in-school suspension may change students' behavior in learning.

More spending per student may or may not raise students' test scores, depending upon whether the budget is used efficiently and effectively (Sander and Krautmann, 1991). If more resources are spent on non-academic items, there will be less effect on students' academic achievement. More per capita personal income may or may not increase test scores. Although higher income families have more resources for their children to achieve better academic performance, children from poor families may have strong incentive to study hard in order to receive higher education to improve their future income and standard of living. 


\section{EMPIRICAL RESULTS}

The original population consisted of the 66 school districts ( 64 of which were parish-wide or county-wide) in the state of Louisiana during academic year 2003-2004. Complete data was available for 63 of the 66 districts, so those 63 comprise the sample. Per capita personal income data was obtained from the Bureau of the Census, U.S. Department of Commerce. Other data came from the Department of Elementary and Secondary Education of Louisiana. In many previous studies, the ACT or SAT score was employed in evaluating students' academic performance to compare with other states. However, the available data for school districts refers to K-8. Therefore, the IOWA test score is used because students are required to take it in the $3^{\text {rd }}, 5^{\text {th, }} 6^{\text {th }}$, and $7^{\text {th }}$ grades. The IOWA test is standardized nationally, and its test scores for Louisiana can be compared with other states and the national average.

Table 1 compiles basic statistics for the IOWA test index and explanatory variables. Some of the variables show large variations due to different social and economic conditions in the parishes. As shown, the IOWA index ranges from a high of 35.4 to a low of 14.4 with an average of 25.3. Percent of qualified teachers varies from $52.9 \%$ to $97.3 \%$. Spending per student ranged from $\$ 5,654$ to $\$ 10,316$ and varied as much as $\$ 4,662$ among parishes. Percent of students receiving free lunch shows more disparity ranging from a low of $26.7 \%$ to a high of $86.9 \%$.

Table 1: Statistics Of The Variables

\begin{tabular}{cccccc}
\hline & Mean & Median & Maximum & Minimum & Std. Dev. \\
\hline IOWA & 25.32 & 24.80 & 35.40 & 14.40 & 4.97 \\
ATTEND & 93.96 & 94.05 & 95.50 & 92.00 & 0.82 \\
SIZE & 55.73 & 53.65 & 85.60 & 29.20 & 14.73 \\
QUAL & 87.15 & 89.40 & 97.30 & 52.90 & 9.26 \\
DISC & 9.55 & 8.15 & 29.20 & 0.00 & 6.71 \\
EXP & $7,112.56$ & $6,888.50$ & $10,316.00$ & $5,654.00$ & 843.56 \\
POV & 55.78 & 55.50 & 86.90 & 26.70 & 13.82 \\
PCPI & $22,485.15$ & $21,690.50$ & $31,639.00$ & $17,183.00$ & $3,617.86$ \\
\hline
\end{tabular}

Table 2: Least Squares Regression - The Dependent Variable Is The IOWA Test Index Dependent Variable: LOG(IOWA)

Method: Least Squares, Sample: 1 66, Included observations: 63, Excluded observations: 3

\begin{tabular}{|c|c|c|c|c|}
\hline Variable & Coefficient & Std. Error & t-Statistic & Prob. \\
\hline $\mathrm{C}$ & -4.315627 & 6.183460 & -0.697931 & 0.4882 \\
\hline LOG(ATTEND6) & 2.607538 & 1.348347 & 1.933878 & 0.0583 \\
\hline LOG(SIZE120) & 0.121391 & 0.052509 & 2.311799 & 0.0246 \\
\hline LOG(QUALIFIED) & 0.351424 & 0.131961 & 2.663087 & 0.0101 \\
\hline LOG(SUSPEN1) & 0.022477 & 0.012730 & 1.765694 & 0.0830 \\
\hline LOG(EXPSTUD) & -0.259962 & 0.124213 & -2.092870 & 0.0410 \\
\hline LOG(FREELUNCH) & -0.577283 & 0.052516 & -10.99256 & 0.0000 \\
\hline LOG(PCPI) & -0.180466 & 0.089403 & -2.018568 & 0.0484 \\
\hline R-squared & 0.812676 & \multicolumn{2}{|c|}{ Mean dependent var } & 3.221936 \\
\hline Adjusted R-squared & 0.788835 & \multicolumn{2}{|c|}{ S.D. dependent var } & 0.195873 \\
\hline S.E. of regression & 0.090009 & \multicolumn{2}{|c|}{ Akaike info criterion } & -1.859649 \\
\hline Sum squared resid & 0.445588 & \multicolumn{2}{|c|}{ Schwarz criterion } & -1.587505 \\
\hline Log likelihood & 66.57895 & \multicolumn{2}{|c|}{ F-statistic } & 34.08699 \\
\hline Durbin-Watson stat & 2.161417 & \multicolumn{2}{|c|}{ Prob(F-statistic) } & 0.000000 \\
\hline
\end{tabular}

Due to zero values in 3 parishes, the sample size used in the empirical analysis is 63. Both White heteroskedasticity-Consistent method and the least squares method were employed to estimate the parameters. Results based on the least squares method are reported in Table 2 because the former method does not improve the outcome much. As shown, $81.3 \%$ of the variation in test scores can be explained by the seven right-hand side variables. The coefficients for QUAL and POV are significant at the 1\% level, the coefficients for SIZE, EXP and PCPI are significant are significant at the 5\% level, and the coefficients for other variables are significant at the $10 \%$ level. It is 
interesting to note that spending per student has a negative impact on students' test scores. It may suggest that test scores are influenced not by the amount of spending but by how the budget is utilized effectively and efficiently to provide quality education. Based on the estimated coefficient, the IOWA test index is expected to rise by $2.6 \%$ if the attendance increases by $1.0 \%$. If qualified teachers increase by $1.0 \%$, the IOWA test index should increase by $0.35 \%$. On the other hand, if the percent of students receiving free lunch rises by $1 \%$, the test score would decline by $0.58 \%$.

Teacher salary is also considered. However, the sign is positive but insignificant. Part of the reasons is that spending per student includes all the expenditures including teacher salary and that these two variables are highly correlated and would cause the statistical problems in empirical work.

In comparison, our study has similar findings as reported by Sander and Krautmann (1991) that income or poverty affects test scores and that higher spending per student did not improve test scores. We also provide empirical evidence on whether other policy and socioeconomic variables would affect test scores.

\section{SUMMARY AND CONCLUSIONS}

In this study, we have examined the determinants of test scores for the state of Louisiana based on 63 of the state's district school systems for the academic year 2003-2004. We find that a higher test score is associated with higher attendance, smaller class size, a higher percentage of qualified teachers, more discipline, lower spending per student, and a lower poverty rate. Higher income may not guaranty a higher test score because there are other factors that would affect test outcomes. There are several policy implications. First, in determining the impact of spending on student academic performance, it is not the amount of spending but whether budget is utilized efficiently and effectively. Second, the importance of having certified teachers, qualified to teach in their fields, cannot be understated. Clausen (Anderson, 2000) indicated that the "single most important factor in improving education is assuring that we have a qualified teacher in every classroom." State and local governments should continue to improve and monitor this program in the expectation that public school teachers are qualified to teach and possess the ability to learn the latest developments in their fields. Third, the government needs to provide more support for a smaller class size in order to provide better quality instruction.

There may be areas for future research. If the data is available, time series analysis at the state level may be considered in order to find potential changes in regression parameters. Some of other socioeconomic variables may be considered. A relatively high percent of welfare recipients in a parish may affect the environment for some of the students to pursue a better education. The number of single parents may be another variable to be considered due to its potential negative impact on student academic performance.

\section{REFERENCES}

1. $\quad$ Anderson, B. (2000, June 4) Clausen Sees Big Shortage of Teachers, Sunday Advocate, A1+.

2. Card, D. and Payne, A. A. (1998) School Finance Reform, the Distribution of School Spending, and the Distribution of SAT Scores, NBER Working Paper: 6766.

3. Chang, H. S. and Hsing, Y. (1996) A Study of Demand for Higher Education at Private Institutions in the U.S.: A Dynamic and General Specification, Education Economics, 4, pp. 267-278.

4. Cook, M. D. and Evans, W. N. (2000) Families or Schools? Explaining the Convergence in White and Black Academic Performance, Journal of labor Economics, 18, pp. 729-754.

5. Currie, J. and Thomas, D. (1999) The Intergenerational Transmission of 'Intelligence': Down the Slippery Slopes of the Bell Curve, Industrial Relations, 38, 297-330.

6. Dayhoff, D. A., (1991) High School and College Freshmen Enrollments: the Role of Job Displacement, Quarterly Review of Economics and Business, 31, pp. 91-103.

7. Dee, T. S, and Jackson, L. A. (1999) Who Loses HOPE? Attrition from Georgia's College Scholarship Program, Southern Economic Journal, 66, pp. 379-390.

8. Dynarski, M. R. (1985) The Scholastic Aptitude Test: Participation and Performance, UC Davis Economics Department Working Paper: 258. 
9. Dynarski, M. and Gleason, P. (1993) Using Scholastic Aptitude Test Scores as Indicators of State Educational Performance, Economics of Education Review, 12, pp. 203-211.

10. Graham, A. E. and Husted, T. A. (1993) Understanding State Variations in SAT Scores, Economics of Education Review, 12, pp. 197-202.

11. Henry, G. T. and Rubenstein, R. (2002) Paying for Grades: Impact of Merit-Based Financial Aid on Educational Quality, Journal of Policy Analysis and Management, 21, pp. 93-109.

12. Husted, T. A. and Kenny, L. W. (2000) Evidence on the Impact of State Government on Primary and Secondary Education and the Equity-Efficiency Trade-Off, Journal of Law and Economics, 43, pp. $285-308$.

13. Krueger, A. B. and Whitmore, D. M. (2001) The effect of Attending a Small Class in the Early Grades on College-Test Taking and Middle School Test Results: Evidence from Project STAR, Economic Journal, 111, pp. 1-28.

14. Peraita, C. and Pastor, M. (2000) The primary dropout in Spain: the influence of family background and labor market conditions, Education Economics, 8, 157-168.

15. Sander, W. (1993) Expenditures and Student Achievement in Illinois: New Evidence, Journal of Public Economics, 52, pp. 403-416.

16. Sander, W. and Krautmann, A. C. (1991) Local Taxes, Schooling, and Jobs in Illinois, Economics of Education Review, 10, pp. 111-121. 
NOTES 